\title{
Analysis of Scenarios to Adapt to Climate Change Impacts in the Rio Conchos
} Basin

\author{
Eusebio Ingol-Blanco ${ }^{1}$ and Daene C. McKinney ${ }^{2}$
}

${ }^{1}$ Center for Research in Water Resources, University of Texas at Austin, Austin, TX 78712; PH (512) 471-0031; FAX (512) 471-0072; email: ingrecurhid@mail.utexas.edu

${ }^{2}$ Center for Research in Water Resources, University of Texas at Austin, Austin, TX 78712; PH (512) 471-5644; FAX (512) 471-0072; email: daene@aol.com

\begin{abstract}
This investigation assesses some water management scenarios to adapt to and mitigate the impacts of climate change on the water resources of the Rio Conchos Basin, a main tributary of the bi-national Rio Grande Basin. The water problems in the basin are characterized by recurrent long drought periods, increasing water demands, and low efficiencies; consequently, significant deficits are experienced, not only in the water system, but also for water delivery to the USMexico 1944 treaty. Future climate change will exacerbate the intense competition for water resources on both sites of the border. First, an assessment was made of climate change impacts on water resources of the basin under IPCC emission scenarios A2 and A1B for the period 20402099. Second, simulation and analysis was done of water management scenarios that have the potential to mitigate the effects of climate change. Because a reduction in river discharge is expected, these scenarios envision an increase in groundwater use, especially in drought periods, and a decrease in water demands and an improvement in water use efficiency. Under climate change conditions, results show that reliability and resiliency of the water system will tend to decrease; consequently, the vulnerability of the system increases over the time. Furthermore, the proposed scenarios indicate some adaptation measures that could make the system more reliable and less vulnerable in meeting water demands for irrigation and municipal uses.
\end{abstract}

Key words: Climate change, water scenarios, adaptation and mitigation, Rio Conchos.

\section{Introduction}

Under climate change conditions, many water systems are projected to be less reliable and more vulnerable in meeting user demands, exacerbating existing competition for water resources. At the global scale, water demand will grow in the next decades due to population growth, and due to substantial changes in irrigation water demand as a result of climate change. In general, negative effects of climate change on water resource systems will complicate changing economic activity, water quality, increasing population, land use change and urbanization. A reduction of available water resources is expected in regions where runoff is projected to decrease; conversely, where rainfall increases are expected, increased water supply is projected. However, the benefit of this might be reduced by negative effects of higher variability of precipitation and seasonal runoff in water supply, food risks, and water quality (IPCC, 2008). 
This paper evaluates the performance of the Rio Conchos Basin water system, a main Mexican tributary of the Rio Bravo/Grande, under climate change emission scenarios A1B and A2 and the potential impact on the water treaty signed between Mexico and the US in 1944. Indicators of reliability, resiliency, and vulnerability of maximum deficit (Hashimoto et al. 1982; Fowler et al. 2003; Ajami et al. 2008) are used to assess the system performance for the period 2040-2060 relative to the baseline scenario 1980-1999. The Rio Conchos Basin, located in northern Mexico (see Fig. 1), has a drainage area around $68,000 \mathrm{~km}^{2}$ and contributes with more than $55 \%$ of the water delivered to the US under the 1944 treaty. In the last decades, recurrent drought periods have occurred in the Rio Conchos Basin, increasing the competition for water resources in both sides of the border. To analyze and evaluate adaptive measures to mitigate the impacts of climate change, an integrated water resources planning model for the Rio Conchos Basin was developed using the Water Evaluation and Planning Software (SEI 2007).

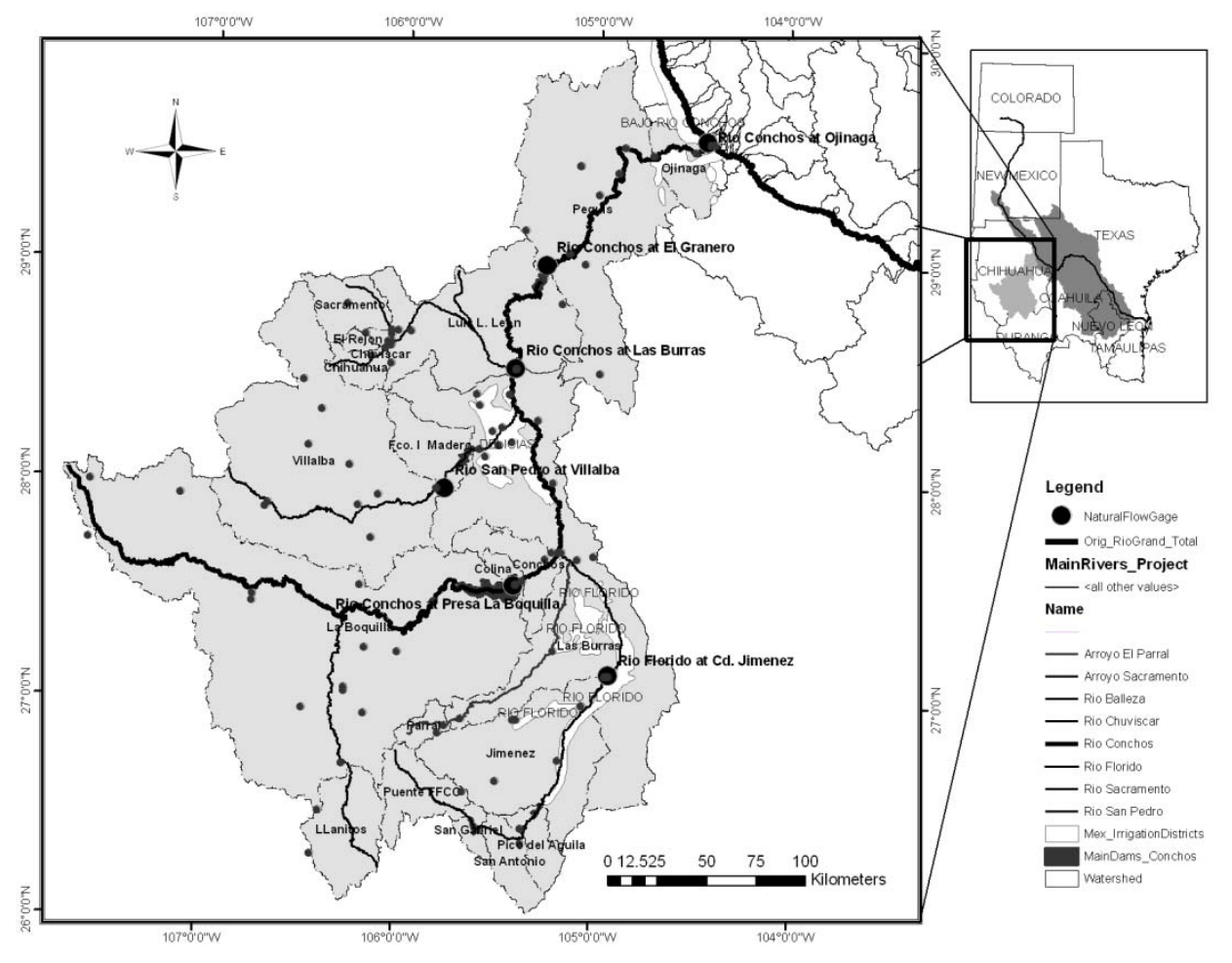

Figure 1. Location of the study area

\section{Methodology}

\section{Integrated water resources planning model}

A water resources planning model for the Rio Conchos Basin was developed using WEAP software. The model integrates two parts: hydrologic and water management modeling. The WEAP soil moisture method was used to represent the hydrological behavior of the Rio Conchos Basin (Ingol-Blanco and McKinney 2010). The second part integrates water management into the hydrologic model. Five main reservoirs, operation rules, municipal and irrigation water 
demand, aquifers, water distribution policies, return flows, stream gages, and transmission links are represented in the water planning model. A yearly demand with monthly variation is used to represent water demands; priorities and consumptive use are set in the model. Constraints are defined for maximum flow in transmission links for demand points that use water from reservoirs, which are linked to special operation rules. System losses and losses to the Meoqui aquifer were established in the return flows from Irrigation District 005 Delicias. The model was calibrated using historical streamflow, storage reservoir volumes, irrigation and municipal water deliveries, water distribution rules, and priorities.

\section{Groundwater modeling}

Data was extracted from the Rio Grande Bi-National Geodatabase (Patiño and McKinney 2005). The Meoqui-Delicias and Jimenez-Camargo areas use groundwater for irrigation and the Chihuahua-Sacrament area uses groundwater used for municipal purposes. WEAP has four options to simulate the interaction between groundwater and surface water (SEI 2007). In this research, we use a combination of the deep soil layer of the WEAP soil moisture method and the specific groundwater-surface water flow method. For further information about the soil moisture method applied to the Rio Conchos Basin, the reader is referred to Ingol-Blanco and McKinney (2010). Fourteen aquifers were included in the WEAP model. Reported volumes approved and used for irrigation are available only for the Meoqui aquifer with a total of 189 million $\mathrm{m}^{3}$ for Irrigation District 005 Las Delicias, and a maximum withdrawal of around 410 million $\mathrm{m}^{3}$ per year.

\section{GCMs and Climate change scenarios}

This research uses statistically downscaled temperature and precipitation from the World Climate Research Programme's (WCRP's) Coupled Model Intercomparison Project phase 3 (CMIP3) multi-model dataset (Maurer et al. 2007) for emission scenarios A2 and A1B. Statistically downscaled results from five GCMs were selected: CGCM31 (Canada), CCSM3 (US), ECHAM5 (Germany), MIROC3.2 (Japan), and HadCM3 (UK). A skill-weighted multimodel ensemble was used to assess the system performance under future climate change (Ingol and McKinney 2011).

\section{Baseline scenario definition}

A time period of twenty years was selected to create a baseline with which to compare future water availability and performance under climate change in the Rio Conchos Basin. It is assumed that water demands, water system conditions, and land use do not change over this period. Furthermore, a water demand at the confluence of the Rio Conchos and Rio Grande to satisfy the requirements of the 1944 Mexico-US treaty was fixed in the model. This requires a delivery of about 711 million $\mathrm{m}^{3}$ per year (IBWC, 2010). This value is temporally distributed using an average monthly variation from the historical baseline (1980-1999). The prescribed annual demand was estimated considering the annual average flow contribution of the Rio Conchos basin (55\%) from Mexican tributaries and the minimum average annual considered in the treaty (431 million cubic meters).

Water demands for agricultural and municipal uses were obtained from the Water Management Scenarios for the Rio Bravo Basin (Sandoval et al. 2008). Changes are assessed relative to the baseline period (1980-1999). Four priorities for water deliveries were set in the model: 1 
(highest) municipal; 2 (middle) irrigation deliveries from reservoirs; 3 (low) irrigation taken directly from rivers; and 4 (lowest) for deliveries to the water treaty, consistent with practice in the Rio Conchos.

\section{Performance of the water system under climate change}

Indices of reliability, resiliency, and vulnerability are used to assess the performance of the Rio Conchos water system to meet the demands (Hashimoto et al. 1982) for the baseline, climate change, and adaptation scenarios. First a criterion, $\mathrm{C}$, is established for each water supply source where an unsatisfactory condition occurs when a specified demand is not met. The annual time series of coverage demand, $\mathrm{X}_{\mathrm{t}}$ is assessed in meeting the criterion $\mathrm{C}_{\mathrm{t}}$ which is defined as the total demand that needs be supplied in each time step. Water supply from four main reservoirs, rivers, and groundwater are available to satisfy water demands for municipal and irrigation users. Furthermore, an index $\mathrm{Z}_{\mathrm{t}}$ is defined to quantify a satisfactory $(\mathrm{S})$ or unsatisfactory $(\mathrm{U})$ state of the water system on the basis of the criterion, $C_{t}$ (Hashimoto et al. 1982).

\section{Sustainability index}

A sustainability index is defined as a measure of the overall performance of the water system under certain conditions and management policies. In this research, we use a sustainability index that combines the reliability, resilience, and relative vulnerability of the system (Loucks 1997; Sandoval et al 2011).

\section{Simulation of water management scenarios to adapt to climate change}

Water management measures designed to help adapt and mitigate the effects of climate change are simulated and tested. Thus, basin water users and managers are provided with an understanding of some of the possible adaptation measures that may be implemented in the future.

Scenario I: Maintain current irrigation water demand under an increasing municipal demand for the period 204099. This scenario considers no improvement in the current water system and no change in the crop demands, but a significant increase in municipal demand. Future population in the Rio Conchos Basin was projected using an arithmetic method, extrapolated to estimate the future municipal demands.

Scenario II: Increase water use efficiencies in all irrigation districts. This scenario includes two parts: (1) increase conveyance efficiency in the Rio Conchos Basin from $61 \%$ to $76.5 \%$ through improvements in the current system such as control structures (gates, dams, and distribution system), lining of main canals with reinforced concrete, improvement of irrigation infrastructure land, training and technical support for farmers and decision makers; (2) increase average water application efficiency from $54 \%$ to $80 \%$ using pressurized irrigation systems. This scenario also considers the same increase in municipal demand as Scenario I.

\section{Results}

Historical calibration of the water planning model

The model was calibrated using historical flows from four stream gages, historical storage volumes from five reservoirs, and historic water deliveries (including the flow requirement to the 
treaty at the Rio Grande confluence). Figure 2 shows a comparison between historical and simulated storage in La Boquilla reservoir for the period 1980-99. The performance of the model in simulating the monthly storages indicates a good agreement, with a coefficient Nash of 0.70 and a relative error less than $5 \%$.

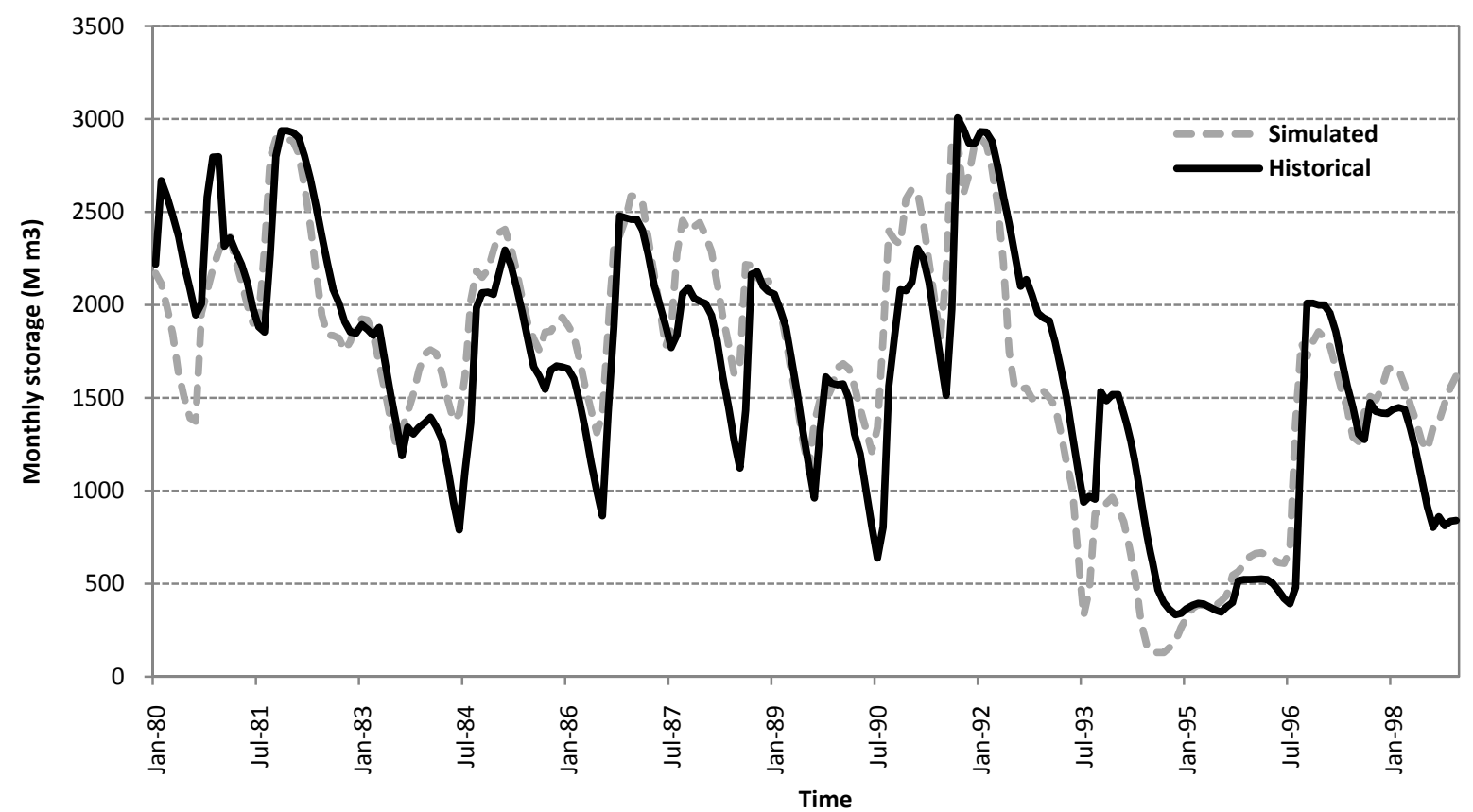

Figure 2. Comparison between historical and simulated storage for La Boquilla reservoir.

\section{Water system performance}

The performance of the water system was evaluated for the period 2040-2099 relative to the historical period 1980-99. Figure 3 shows the reliability (Fig. 3a) and the vulnerability (Fig. 3b) for groundwater and surface water users in the Rio Conchos Basin, as well as the water treaty. Under both emission scenarios $\mathrm{A} 2$ and $\mathrm{A} 1 \mathrm{~B}$, the results indicate that the reliability of water supply for all demands is lower than the baseline scenario, with less negative impact for scenario A1B as expected. The relative change (percent of change from the baseline) indicates that reliability will be reduced in the range of $18-25 \%$ for irrigation and groundwater, and from $2-7 \%$ for municipal supply (the highest priority for water delivery); however, it will be more severe if we consider increasing municipal demand over time.

Since these indicators are negatively correlated, increased vulnerability is seen in Fig. $3 \mathrm{~b}$. The relative change suggests an increase of the annual maximum deficit of around $30 \%$ for irrigation demands. The maximum deficit for municipal use increases more than $90 \%$. Furthermore, a slight reduction in vulnerability is shown for groundwater supply that could be related to the duration of drought and its magnitude in the Rio Conchos Basin. 

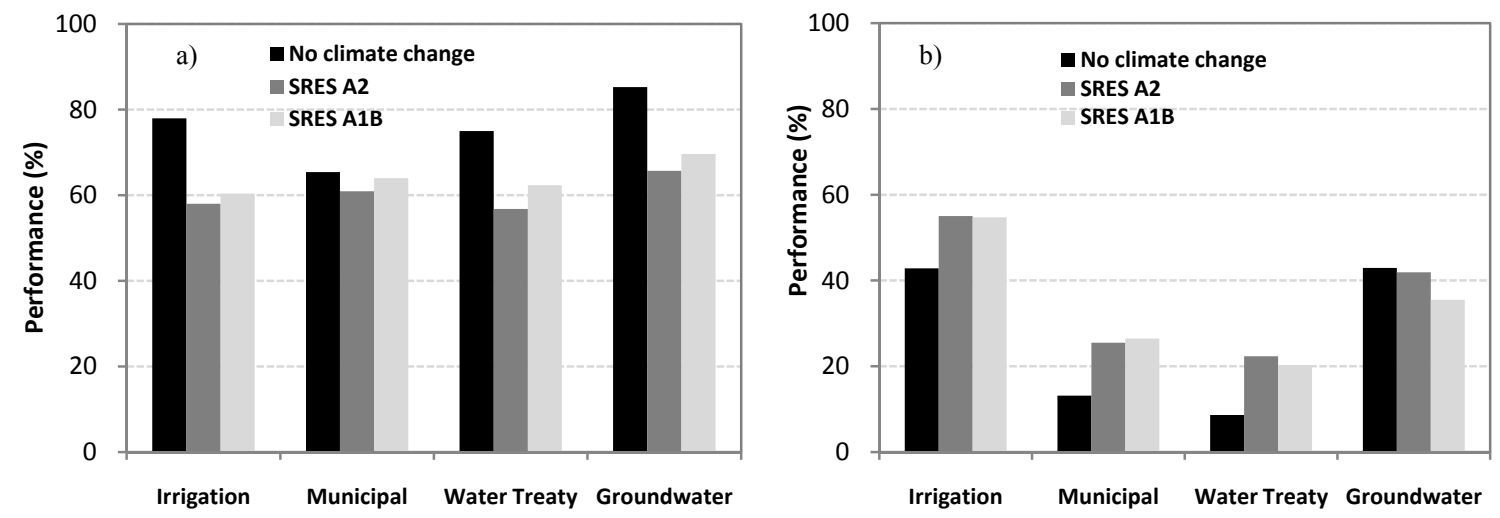

Figure 3. Basin performance under climate change. a) Reliability, and b) Vulnerability

Water management scenario to adapt climate change impacts

Figure 4 presents, the system performance under emissions scenario A2. Scenario I considers a substantial increment of municipal demand. Under this condition, the water supply system is less reliable and more vulnerable with a strong impact on municipal users. However, with the water management policy stated in Scenario II, which includes system improvement, the system reliability increases; consequently, the vulnerability may be reduced considerably. The relative change indicates an increase of the reliability of more than $50 \%$ for irrigation and municipal users, with a substantial reduction of the vulnerability (25\% for irrigation and $45 \%$ for municipal users). On the other hand, it should be noted that for groundwater supply, the reliability decreases more than $10 \%$ due to the improvement of the system, which is translated to an increase of the efficiency of water use; consequently, the groundwater recharge is reduced.

\section{Water treaty}

Under the emission scenarios A1B and A2, the reliability of deliveries to the treaty is projected to be reduced about $17-24 \%$ relative to the baseline, and the vulnerability is projected to increase from $9 \%$ in the baseline to more than $20 \%$ for both emission scenarios. Applying the adaptive measures, treaty deliveries improve with respect to Scenario I.
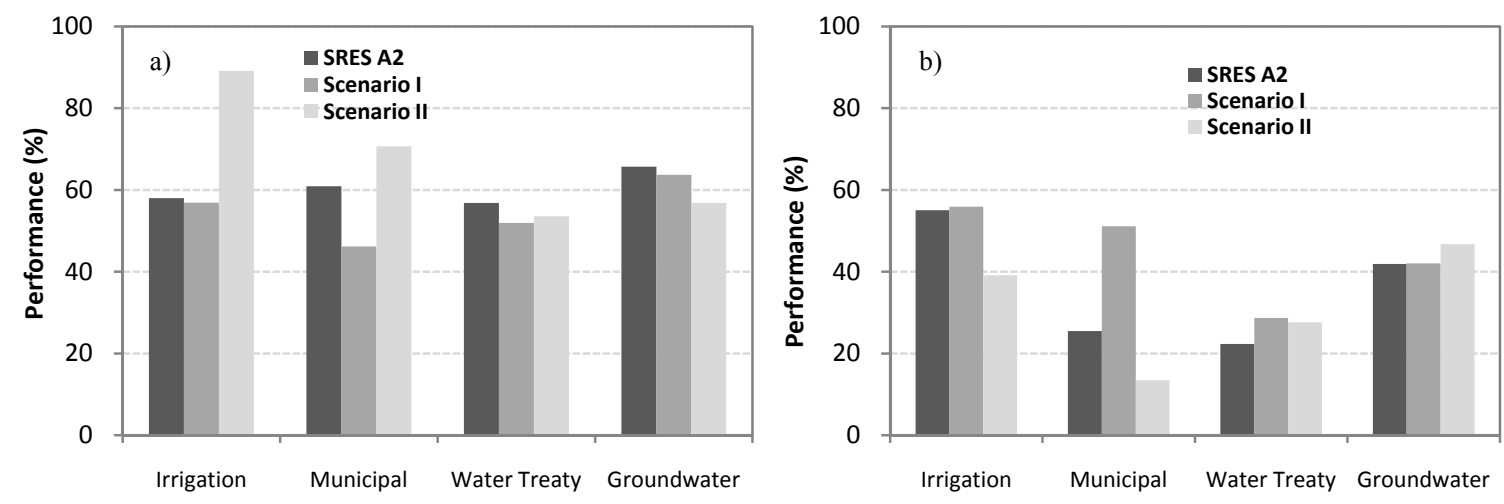

Figure 4. Basin performance under adaptation measures. a) Reliability, and b) Vulnerability

\section{Sustainability of the water system}

The combined performance of water system in meeting water demands in the Rio Conchos basin and the treaty is shown in Table 1, computed on the basis of reliability, resiliency, and 
vulnerability of annual maximum deficit. Under both emission scenarios, the system is less sustainable than the baseline scenario; even more, the performance is projected to be more critical, if the condition of Scenario I considered (increasing municipal demand over time and no adaptive measures). The adaptive measures of Scenario II increases the sustainability for municipal and irrigation users, and treaty deliveries; however, as noted earlier, groundwater shows a decline due to the reduction of aquifer recharge. In general, irrigation and groundwater supply will be reduced.

Table 1. Sustainability Index for the Rio Conchos Basin Under Climate Change

\begin{tabular}{lcccc}
\hline \multicolumn{1}{c}{ Scenario } & Irrigation & Municipal & Water Treaty & Groundwater \\
\hline Baseline & 64 & 70 & 77 & 73 \\
Emissions Scenario A2 & 49 & 64 & 61 & 56 \\
Emissions Scenario A1B & 51 & 65 & 66 & 62 \\
\hline Scenario I & 48 & 47 & 55 & 55 \\
Scenario II & 68 & 73 & 56 & 48 \\
\hline
\end{tabular}

\section{Conclusions}

This research demonstrates that the water availability in the Rio Conchos Basin will likely become more vulnerable to future drought events under climate change; however, adaptive strategies may play an important role in reducing the negative effects on the system. Using a skill-weighted multi-model ensemble of results from five GCMs for emission scenarios A1B and A2 in a hydrologic water management model shows that the reliability of water supply will decrease for all users; even more, this condition is projected to be more critical if an increased municipal demand is considered. The vulnerability for irrigation, municipal, and water treaty deliveries increases substantially over time, which could exacerbate even more the competition for water resources on both sides of the border. The effect is less negative for emissions scenario A1B as expected. The simulation of the adaptive measures show that may be possible to improve the performance of the system, becoming more reliable, less vulnerable, and more sustainable. The overall performance of the system expressed in terms of a sustainability index also indicates that the system will probably be less sustainable under climate change; nevertheless, a substantial improvement of its performance indicated with the implementation of adaptation measures.

\section{References}

Ajami, N.K; Hornberger, G.M; and Sunding, D.L. (2008). "Sustainable water resources management under hydrological uncertainty". Water Resour. Res; 44, W11406, doi:10.1029/2007WR006736, 1-10.

Fowler, H. J., Kilsby, C.G; and O'Connell, P.E. (2003). "Modeling the impacts of climatic change and variability on the reliability, resilience, and vulnerability of a water resource system". Water Resour. Res., 39(8), 1222, doi:10.1029/2002WR001778, 1-11.

Hashimoto, T., Stedinger, J.R; and Loucks, D.P. (1982). "Reliability, resiliency, and vulnerability criteria for water resource system performance evaluation". Water Resour. Res., 18(1), 14 - 20, doi:10.1029/WR018i001p00014, 14-20. 
IBWC - International Boundary and Water Commission (2010). "Rio Grande Historical Mean Daily Discharge Data." <http://www.ibwc.state.gov/Water_Data/histflo1.htm> (Dec. 31, 2010).

Ingol-Blanco, E., and McKinney, D.C. (2010). "Development of a hydrological model for the Rio Conchos Basin". Paper submitted to the J. Hydrological Engineering.

Ingol-Blanco, E., and McKinney, D.C. (2011). "Modeling Climate Change Impacts on Flow in the Rio Conchos Basin". Paper submitted to the J. Water Resour. Planning and Management.

IPCC - Intergovernmental Panel on Climate Change. (2008). "Climate Change and Water". Contribution to the Fourth Assessment Report of the Intergovernmental Panel on Climate Change. Bates, B.C., Kundzewicz, Z.W., Wu, S., and Palutikof, J.P. IPCC technical paper VI.

http://www.ipcc.ch/ipccreports/tp-climate-change-water.htm

Loucks, D.P. (1997). “Quantifying trends in system sustainability”. J. of Hydrol. Sci; 42(4), 513530.

Maurer, E. P., L. Brekke, T. Pruitt, and P. B. Duffy (2007), 'Fine-resolution climate projections enhance regional climate change impact studies', Eos Trans. AGU, 88(47), 504

Patiño-Gomez, C; and McKinney, D.C. (2005). "GIS for Large-Scale Watershed Observational Data Model". Center for Research in Water Resources, Online Report 05-07, University of Texas at Austin, 283 pp. www.crwr.utexas.edu/reports/2005/rpt05-7.shtml

Sandoval-Solis, S., D. C. McKinney and R. L. Teasley (2008). Water Management Scenarios for the Rio Grande/Bravo Basin, Center for Research in Water Resources, Online Report 08-01, University of Texas at Austin. www.crwr.utexas.edu/reports/2006/rpt08-01.shtml

Sandoval-Solis, S., D. C. McKinney, and D. P. Loucks. (2011) Sustainability Index for Water Resources Planning and Management, J. Water Resour. Planning and Management, accepted, in press. Doi: 10.1061/(ASCE)WR.1943-5452.0000134

SEI - Stockholm Environment Institute. (2007). "Water Evaluation and Planning System, WEAP”. Boston, U.S.A. 